\title{
The financial modeling in industrial building using the method of hierarchies analysis
}

\author{
Olga Maksymchuk ${ }^{1}$, Oksana Baulina $^{1}$, and Vladislav Klyushin ${ }^{1, *}$ \\ ${ }^{1}$ Volgograd State Technical University, The Department Of Management And Urban Development And Construction, 400074 \\ Volgograd, Russia
}

\begin{abstract}
The processes in the activity of construction companies which are involved in the construction of industrial objects, bridges and roads, and the factors affecting the value of these processes and the organization's financial stability have been investigated. A comparative analysis of the construction companies according to the criteria for stability (financial, economic, organizational, innovation, investment) has been implemented using the analytic hierarchy method; financial models of studied construction companies have been developed, the forecast evaluation of their expediency has been made.
\end{abstract}

\section{Introduction}

In the conditions of the stagnant domestic economy, due to the current unfavorable macroeconomic situation, the theme of the construction industry is particularly important. In the conditions of a quick rise of mortgage loans rates and the reduction in real incomes, the building sector has a co-financing problems of activity from the population, on the other hand there is a quick rise of the cost price of building work in connection with the growth rates of the energy, rail and road transport, the rising cost of construction materials. So, according to the Federal Service of state statistics in the Russian Federation, in the 1 st quarter $201424 \%$ of the respondents of the building sector mentioned the high cost of building materials among the factors limiting production activities of construction companies but in the 1 st quarter 2015 this index is already $32 \%$. This is due to the use of imported components, this also concerns the production of dry building mixes using imported modifiers and production of aluminum constructions, cable and wire products, and roofing materials. At the same time, according to the study "Business surveys Lab by E.T. Gaidar", 22\% of enterprises in the construction industry faced with a lack of domestic analogues of equipment and raw materials, $18 \%$ of companies noted the low quality of domestic analogues. In these unfavorable economic conditions, the participants of the construction sector face with problem of its own stability providing, including the use of various financial models in the development of management decisions.

\section{The definition of the terminology}

Financial modeling is a process of building a real and expected situation in the activity of the enterprise in the market. All the indexes that will be used in the financial model of the enterprise, can be divided into the following groups: property (assets), liabilities, cash flow (receipts and payments funds), income and expenses. That is, all the results of the calculations which were done using the model presented in the usual form of a balance sheet, the report of financial results and the report of cash flow movement according to the arbitrary (selected) date in the future.

The financial model is a tool for monitoring the current situation in the company and the development of financial policy which provides sustainability of the enterprise in the conditions of changing external environment. The financial model is iterative in nature and should be developed according to the principle "from simple" to "complex". During the year, the company's financial model can be corrected, to put down the actual information can be noted in the passed months instead of the planned and the financial results can be controlled so, that the negative trends will be shown and there will be a clear understanding of what they will lead the company.

Comparison of models of different companies allows to choose the most stable and on the basis of integrated indexes to make decisions, such as choosing a potential partner, it also is important to ensure the own stability of the enterprise.

\section{Question, Hypotheses, and methods}

Among the methods which can be used in the solving the tasks of enterprises stability evaluation there is

\footnotetext{
*Corresponding author: vladislav-klushin@yandex.ru
} 
regression analysis method, the theory of unclear plurality and multivariate analysis method, known as the analytic hierarchy method (AHM), which is the procedure of system analysis for hierarchy presentation of elements that define the essence of any problems. The method consists in decomposing of the problem into simpler components and its further processing sequence of statement of person, who makes decision by pairwise comparisons. The intensity of elements interaction is expressed by a hierarchy of elements in numerical form. The AHM includes synthesis procedures of multiple statements to obtain the priority criteria and find alternative solutions. The identity and decomposition principles involve problem structuring in the form of a hierarchy or a network, that is the first step in the application of the AHM to solve that problem.

Hierarchy stability model presentation is built from the top (the purpose - in terms of management assessment of the stability of enterprises, level 1), through the intermediary of the second level (the stability criteria which influence subsequent levels) to the lowest third level (which is a list of alternatives - the analyzed companies in which the level of stability is investigated).

The author's model identified five criteria that determine the stability, namely: 1) Financial stability; 2) Economic stability; 3) Organizational stability; 4) Investment stability; 5) Innovative stability. The main task of our model realization is the ranking of enterprises as well as the compilation of the sample by the criterion of "the most high stability." For this we introduce the mathematical description of this concept. Let a linear combination

$$
\sum_{k=1}^{n} W_{k} r_{k}=W_{c}
$$

defines the sought degree of enterprises stability by the criteria adequacy of the chosen linguistic variable. Then the average value of the coefficient of enterprise stability level can be calculated using the formula:

$$
K_{a c p}=\frac{\sum_{i=1}^{n} K_{i}}{n}
$$

The excess $K_{a I}$ compared with mean value is calculated according to the formula:

$$
\delta \%_{K_{a I}}=\left|\frac{K_{a I}-K_{a c p}}{K_{a c p}}\right| \cdot 100 \%
$$

Where $K_{a l}, K_{a I I}, K_{a I I}-K_{a n}-$ analysis objects (analyzed enterprises).

For the selection of the most stable enterprises, the number of enterprises can be arbitrary and is established by the user independently, for each of the analyzed companies there is necessary the following information for the financial report: F1-balance sheet, F2, financial results report, F4, cash flow movement report, F5 application to the balance sheet. On the basis of these financial reports the calculation of analytic indexes (coefficients) is carried out, the indexes are grouped by each type of stability: financial, economic, organizational, investment, innovation. For receiving of this system of indexes we have carried out financial and economic analysis of economic activity of the analyzed companies for 2013- 2015 and produced a sample of indexes that form the system of linguistic variables. In the analysis the attention is paid to all expenses profitability assessment, which shows how much profit from main activity falls on 1 monetary unit of general operating expenses. The results of the analysis were used for the automated creation of matrices of binary significances ratio according to the criteria of stability. Integral priorities vectors of financial stability; economic stability; organizational stability; investment stability; innovative stability, calculated for each of the $n$ chosen enterprises, become the basis for matrices formation of binary significances ratio for stability criteria at level of the third hierarchy.

The next step is to apply the synthesis principle that allows to calculate the integral (global) vector of priorities through the final value of the enterprise stability. To identify the global (integral) enterprises priority (according to the previously specified formulas) in the matrix, the local priorities are arranged to each criterion, each vector column is multiplied by the corresponding criteria priority and the result is summarized along each line. It allows to finally rank the investigated companies according to their stability, and that is the solution of the problem.

The analysis of domestic and foreign researchers who pay attention to the stability of the business, allowed the authors to identify a range of indexes which allow to calculate the local stability vectors. When there is the financial component evaluation of the enterprise stability, Russian economists underlined the following factors: solvency, liquidity, creditworthiness and profitability. In assessing these factors of the financial component stability, there is the most spread method of financial coefficients.

In assessing the economic component of the company's stability, there are methods based on the calculation of financial coefficients (intraeconomic financial analysis), as well as indexes of economic activity. Among the factors of the economic component of the enterprise stability, the domestic economists include: success in the market of products, production and technological opportunities of the enterprise, financial opportunities, employment opportunities.

Analysis of the organizational component of the enterprise stability involves the consideration and assessment of such factors as: the organizational structure of the enterprise, the level of corporate culture, the rationality of information flow, development of motivation system.

The indexes for assessing the innovative component of enterprise stability include: indexes of social and technical innovation.

Assessment of the investment stability is implemented on the basis of accounting report information by calculating a range of coefficients.

Thus, we have identified the indexes of financial, economic, institutional, investment and innovation 
enterprise stability, these indexes are based on the analysis which help to select the most stable companies; integrated assessment is carried out using the analytic hierarchy method, allowing to rank companies on the basis of the calculation of global priorities vector.

\section{Result}

The model developed by the authors, was the basis of the computer program FAAC (Functional Analysis Of Activity Companies) (certificate of state registration №2016618552 from 2nd August 2016) and it was tested by the example of the five major domestic construction companies. The program is designed for a wide range of users, including: managers and employees of economic departments, state authorities and local self-government, university professors, students and graduates of economic specialties.

The testing results of the model developed by the author, are presented below (Table 1-5). We note that the first two tables ("Financial Stability" and "Economic stability") are filled with an objective method comparative calculation of financial and economic factors the ratio between the enterprises with each other, and the next three tables ("Organizational stability", "Innovative stability", "Investment stability") - with the use of the subjective method, by expert statement evaluation of person who makes decisions with the use of relative importance scale from 1 to 9 .

Table 1. The calculation of integrated priority vectors for financial stability index with yhe local vectors use of financial coefficients.

\begin{tabular}{|c|c|c|c|c|c|c|c|}
\hline $\begin{array}{c}\text { Local } \\
\text { vectors of } \\
\text { financial } \\
\text { coefficients }\end{array}$ & $\begin{array}{c}\text { The } \\
\text { coeffici } \\
\text { ent of } \\
\text { current } \\
\text { liquidit } \\
y\end{array}$ & $\begin{array}{c}\text { The } \\
\text { coeffici } \\
\text { ent of } \\
\text { autono } \\
\text { my }\end{array}$ & $\begin{array}{c}\text { The } \\
\text { coeffici } \\
\text { ent of } \\
\text { financi } \\
\text { al } \\
\text { leverag } \\
\text { e }\end{array}$ & $\begin{array}{l}\text { i The } \\
\text { coeffici } \\
\text { ent o } \\
\text { capitali } \\
\text { zation }\end{array}$ & $\begin{array}{c}\text { The } \\
\text { coeffici } \\
\text { ent of } \\
\text { quick } \\
\text { liquidit } \\
y\end{array}$ & $\begin{array}{c}\text { The } \\
\text { coeffici } \\
\text { ent of } \\
\text { absolut } \\
\text { e } \\
\text { liquidit } \\
y\end{array}$ & \begin{tabular}{|c} 
Integra \\
l \\
priorit \\
$y$ \\
i \\
vector \\
tFinan \\
cial \\
tabilit \\
stal \\
y»
\end{tabular} \\
\hline $\begin{array}{c}\text { JSC } \\
\text { «Volgomost» }\end{array}$ & 0.13 & 0.15 & 0.17 & 0.03 & 0.24 & 0.52 & 0.18 \\
\hline \begin{tabular}{|c|} 
JSC \\
«Dalmoststro \\
i» \\
\end{tabular} & 0.19 & 0.04 & 0.61 & 0.45 & 0.00 & 0.01 & 0.27 \\
\hline \begin{tabular}{|c|} 
JSC \\
«Mostostroi- \\
$11 »$ \\
\end{tabular} & 0.30 & 0.40 & 0.04 & 0.16 & 0.02 & 0.04 & 0.20 \\
\hline \begin{tabular}{|c|} 
JSC \\
«Mostotrest» \\
\end{tabular} & 0.15 & 0.23 & 0.07 & 0.04 & 0.68 & 0.31 & 0.17 \\
\hline $\begin{array}{c}\text { JSC } \\
\text { «Sibmost } »\end{array}$ & 0.22 & 0.17 & 0.11 & 0.32 & 0.05 & 0.12 & 0.18 \\
\hline
\end{tabular}

Table 2. The calculation of integrated priority vectors for economic stability index with the local vectors use of economic coefficients.

\begin{tabular}{|c|c|c|c|c|c|c|}
\hline $\begin{array}{l}\text { Local vectors } \\
\text { of economic } \\
\text { coefficients }\end{array}$ & $\begin{array}{c}\text { Sale } \\
\text { profitab } \\
\text { ility }\end{array}$ & $\begin{array}{c}\text { Capital } \\
\text { producti } \\
\text { vity }\end{array}$ & $\begin{array}{c}\text { The } \\
\text { coefficie } \\
\text { nt of } \\
\text { availabil } \\
\text { ity }\end{array}$ & $\begin{array}{c}\text { The } \\
\text { turnove } \\
\text { r of } \\
\text { reserves }\end{array}$ & $\begin{array}{c}\text { The } \\
\text { turnove } \\
\text { r of } \\
\text { receivab } \\
\text { les }\end{array}$ & \begin{tabular}{|c} 
Integral \\
priority \\
vector \\
«Econo \\
mic \\
stability \\
$»$
\end{tabular} \\
\hline JSC & 0.30 & 0.27 & 0.16 & 0.36 & 0.12 & 0.20 \\
\hline
\end{tabular}

\begin{tabular}{|c|c|c|c|c|c|c|}
\hline «Volgomost» & & & & & & \\
\hline $\begin{array}{c}\text { JSC } \\
\text { «Dalmoststroi } \\
»\end{array}$ & 0.00 & 0.15 & 0.01 & 0.14 & 0.14 & 0.09 \\
\hline $\begin{array}{c}\text { JSC } \\
\text { «Mostostroi- } \\
11 »\end{array}$ & 0.44 & 0.15 & 0.31 & 0.09 & 0.29 & 0.31 \\
\hline $\begin{array}{c}\text { JSC } \\
\text { «Mostotrest» }\end{array}$ & 0.25 & 0.34 & 0.35 & 0.21 & 0.19 & 0.25 \\
\hline JSC «Sibmost» & 0.01 & 0.09 & 0.17 & 0.19 & 0.26 & 0.16 \\
\hline
\end{tabular}

Table 3. The calculation of integrated priority vectors for organizational stability index with the matrix use of significance binary ratio.

\begin{tabular}{|c|c|c|c|c|c|c|}
\hline $\begin{array}{c}\text { Binary ratio of } \\
\text { enterprises } \\
\text { significance by } \\
\text { criteria } \\
\text { «Organizational }\end{array}$ & $\begin{array}{c}\text { JSC } \\
\text { «Volgo }\end{array}$ & $\begin{array}{c}\text { JSC } \\
\ll \text { Dalmo }\end{array}$ & $\begin{array}{c}\text { JSC } \\
\ll \text { Motost }\end{array}$ & JSC & $\begin{array}{c}\text { JSC } \\
\text { «Sibmos }\end{array}$ & \begin{tabular}{|c|} 
Integral \\
priority \\
vector \\
«Organi \\
zational \\
stability
\end{tabular} \\
\hline stability »" & most» & st-stroi» & roi-11» & rest» & t) & 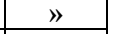 \\
\hline $\begin{array}{c}\text { JSC } \\
\text { «Volgomost» }\end{array}$ & 1.00 & 1.67 & 0.83 & 0.63 & 1.00 & 0.19 \\
\hline \begin{tabular}{|c|} 
JSC \\
«Dalmoststroi»
\end{tabular} & 0.60 & 1.00 & 0.50 & 0.38 & 0.60 & 0.11 \\
\hline \begin{tabular}{|c|} 
JSC \\
«Mostostroi-11» \\
\end{tabular} & 1.20 & 2.00 & 1.00 & 0.75 & 1.20 & 0.22 \\
\hline $\begin{array}{c}\text { JSC } \\
\text { «Mostotrest» }\end{array}$ & 1.60 & 2.67 & 1.33 & 1.00 & 1.00 & 0.27 \\
\hline JSC «Sibmost» & 1.00 & 1.67 & 0.83 & 1.00 & 1.00 & 0.21 \\
\hline
\end{tabular}

The integral priority vectors of financial stability; economic stability; organizational stability; investment stability; innovative stability, calculated for each of the five companies, have become the data for the compilation of the of binary ratio matrix of significances by stability criteria at the level of the $3 \mathrm{~d}$ hierarchy.

Table 4. The calculation of integrated priority vectors for innovative stability index with the matrix use of significance binary ratio.

\begin{tabular}{|c|c|c|c|c|c|c|}
\hline $\begin{array}{l}\text { Binary ratio of } \\
\text { enterprises } \\
\text { significance by } \\
\text { criteria } \\
\text { «Innovative } \\
\text { stability » }\end{array}$ & $\begin{array}{c}\text { JSC } \\
\text { «Volgo } \\
\text { most» }\end{array}$ & $\begin{array}{c}\text { JSC } \\
\text { «Dalmo } \\
\text { st- } \\
\text { stroi» }\end{array}$ & $\begin{array}{c}\text { JSC } \\
\ll \text { Motos } \\
\text { troi-11» }\end{array}$ & $\begin{array}{c}\text { JSC } \\
\text { «Mosto } \\
\text { trest» }\end{array}$ & $\begin{array}{c}\text { JSC } \\
\text { «Sibmo } \\
\text { st» }\end{array}$ & \begin{tabular}{|c|} 
Integral \\
priority \\
vector \\
«Innov \\
ative \\
stability \\
$»$
\end{tabular} \\
\hline $\begin{array}{c}\text { JSC } \\
\text { «Volgomost» }\end{array}$ & 1.00 & 3.00 & 1.20 & 0.86 & 1.00 & 0.23 \\
\hline $\begin{array}{c}\text { JSC } \\
\text { «Dalmoststroi» }\end{array}$ & 0.33 & 1.00 & 0.40 & 0.29 & 0.33 & 0.08 \\
\hline $\begin{array}{c}\text { JSC } \\
\text { «Mostostroi-11» }\end{array}$ & 0.83 & 2.50 & 1.00 & 0.71 & 0.83 & 0.19 \\
\hline $\begin{array}{c}\text { JSC } \\
\text { «Mostotrest» } \\
\end{array}$ & 1.17 & 3.50 & 1.40 & 1.00 & 1.00 & 0.26 \\
\hline JSC «Sibmost» & 1.00 & 3.00 & 1.20 & 1.00 & 1.00 & 0.24 \\
\hline
\end{tabular}

Table 5. The calculation of integrated priority vectors for investment stability index with the matrix use of significance binary ratio.

\begin{tabular}{|c|c|c|c|c|c|c|}
\hline $\begin{array}{l}\text { Binary ratio of } \\
\text { enterprises } \\
\text { significance by } \\
\text { criteria } \\
\text { «Investment } \\
\text { stability }\end{array}$ & $\begin{array}{c}\text { JSC } \\
\text { «Volgo } \\
\text { most }\end{array}$ & $\begin{array}{c}\text { JSC } \\
\ll \text { Dalmo } \\
\text { st- } \\
\text { stroi }\end{array}$ & $\begin{array}{c}\text { JSC } \\
\ll \text { Motos } \\
\text { troi-11 }\end{array}$ & \begin{tabular}{|c|} 
JSC \\
«Mosto
\end{tabular} & $\begin{array}{c}\text { JSC } \\
\text { «Sibmo }\end{array}$ & \begin{tabular}{|c|} 
Integral \\
priority \\
vector \\
«Invest \\
ment \\
stability
\end{tabular} \\
\hline
\end{tabular}




\begin{tabular}{|c|c|c|c|c|c|c|}
\hline $\begin{array}{c}\text { JSC } \\
\text { «Volgomost» }\end{array}$ & 1.00 & 3.00 & 1.20 & 0.86 & 1.00 & 0.23 \\
\hline $\begin{array}{c}\text { JSC } \\
\text { «Dalmoststroi» }\end{array}$ & 0.33 & 1.00 & 0.40 & 0.29 & 0.33 & 0.08 \\
\hline $\begin{array}{c}\text { JSC } \\
\text { «Mostostroi-11» }\end{array}$ & 0.83 & 2.50 & 1.00 & 0.71 & 0.83 & 0.19 \\
\hline $\begin{array}{c}\text { JSC } \\
\text { «Mostotrest» }\end{array}$ & 1.17 & 3.50 & 1.40 & 1.00 & 1.00 & 0.26 \\
\hline JSC «Sibmost» & 1.00 & 3.00 & 1.20 & 1.00 & 1.00 & 0.24 \\
\hline
\end{tabular}

The values of global priorities vector of matrix binary significances ratio by constituting criteria of enterprises stability assessment, are presented in the table below (Table 6).

Table 6. The value of the global priority vector for the index «Enterprise stability».

\begin{tabular}{|c|c|c|c|}
\hline \multicolumn{2}{|c|}{ Stability components } & $\begin{array}{c}\text { The value of } \\
\text { integral priority } \\
\text { vectors }\end{array}$ & Rank \\
\hline 1 & Financial stability & 0.477405058 & 1 \\
\hline 2 & Economic stability & 0.271534589 & 2 \\
\hline 3 & Organizational stability & 0.03962003 & 5 \\
\hline 4 & Investment stability & 0.145676217 & 3 \\
\hline 5 & Innovative stability & 0.065764105 & 4 \\
\hline
\end{tabular}

Furthermore, in the following table VII authors also calculated deviation of integral priority vector component from their average values (absolute and relative values). This calculation makes it possible to fully and more accurately assess which companies have the high stability in terms of their criteria assessment.

Table 7. The integral index of building enterprises stability.

\begin{tabular}{|c|c|c|c|c|}
\hline \multirow[b]{2}{*}{ Enterprises } & \multicolumn{4}{|c|}{$\begin{array}{l}\text { Ranking companies based on the vector of global } \\
\text { priorities }\end{array}$} \\
\hline & $\begin{array}{c}\text { Integral } \\
\text { priorities }\end{array}$ & $\begin{array}{c}\text { Rank } \\
\text { (rating) }\end{array}$ & \begin{tabular}{|c|} 
Absolute \\
deviation \\
from average \\
value of \\
global \\
priority \\
vector
\end{tabular} & $\begin{array}{c}\text { The } \\
\text { deviation } \\
\text { rom average } \\
\text { value of } \\
\text { global } \\
\text { priority } \\
\text { vector, } \%\end{array}$ \\
\hline $\begin{array}{c}\text { JSC } \\
\text { «Volgomost» }\end{array}$ & 0.198474408 & 3 & $\begin{array}{c}- \\
0.001525592 \\
\end{array}$ & $-1 \%$ \\
\hline $\begin{array}{c}\text { JSC } \\
\text { «Dalmoststroi } \\
»\end{array}$ & 0.172136855 & 5 & $\begin{array}{c}- \\
0.027863145\end{array}$ & $-14 \%$ \\
\hline $\begin{array}{c}\text { JSC } \\
\text { «Mostostroi- } \\
11 » \\
\end{array}$ & 0.227262582 & 1 & 0.027262582 & $14 \%$ \\
\hline $\begin{array}{c}\text { JSC } \\
\text { «Mostotrest» } \\
\end{array}$ & 0.217078421 & 2 & 0.017078421 & $9 \%$ \\
\hline ISC «Sibmost» & 0.185047732 & 4 & $\begin{array}{c}- \\
0.014952268 \\
\end{array}$ & $-7 \%$ \\
\hline
\end{tabular}

How to interpret these priorities? From Table 7 it becomes clear that the presence of high financial support of the company (financial stability, rank 1) is perceived by the administrator of the enterprise as the most important criterion in the assessment of stability. In fact, it is more important than the economic stability ( 3 grade) (vector of local priorities 0.477405058 against 0.271534589 ) almost in 2 times and is much more important than organizational stability (rank 5), which has the lowest priority, equal to 0.03962003 (almost in 18 times less).
Thus, implemented stability assessment with the use of AHM, showed that only two companies of 5 companies, (JSC "Mostotrest", JSC "Mostostroi-11") received a positive difference between the average value of global priorities and values of the corresponding linear combinations for each of the studied enterprises (+ $14 \% ;+9 \%$, respectively). Other enterprises are outsiders according to the values of stability.

\section{Conclusion}

The stability assessment method using analytic hierarchy procedure is universal and easy to apply in practice. Its application will increase the accuracy of the management decisions (federal, regional, municipal, departmental, and others) with regard to inter-regional and sectoral distribution of resources, and at the level of individual enterprises - to work most effectively with their own and borrowed capital. In addition, application of this method in an expanded form (with an increase in the number and quality of evaluation criteria of financial, economic, organizational, investment, innovation components stability, and involving the most possible number of assessed companies) allows to evaluate stability of the certain sector.

Developed software product FAAC provides: 1. the calculation of analytic indexes (coefficients) which are grouped for each type of stability: financial, economic, institutional, investment and innovation; 2 . the calculation of the local vectors of priorities for each type of stability; 3. the calculation of the global priority vector, allowing the company to rank for the selection of the most stable of them; 4. Visualization of calculations with diagrams. With the results of the calculations, it is possible not only to select the most stable enterprise, but also to select the most "narrow places" in the activities of each company. The software product "FEP Analiz.1" was used to develop practical recommendations for optimizing the financial models of the analyzed companies, authoring (certificate of state registration number 2014660103 from 01.10.2014).

Application of optimizational financial model of expenses management allows JSC "Dalmoststroy" to increase the level of the marginal income in 2016 from 250961 thousand rub. to 17152 thousand rub. It is also expected the increase of the rate of profit from $-4.76 \%$ to $0.34 \%$, reflecting the increase of the profitability of the company and out of the loss zone.

Application of optimizational financial model of expenses management allows JSC «Volgomost»" to increase the level of the marginal income in 2017 from 2235165 th. rubles to 2715034 th. rubles. It is also expected the increase of the rate of profit from $11.5 \%$ to $16.3 \%$, reflecting the increase of the company's profitability.

Application of optimizational financial model of expenses management allows JSC «Mostostroi-11»" to increase the level of the marginal income in 2017 from 2281077 th. rubles to 2452689 th. rubles. It is also expected the increase of the rate of profit from $14.7 \%$ to 
$17.7 \%$, reflecting the increase of the company's profitability.

Application of optimizational financial model of expenses management allows JSC «Mostostroi»" to increase the level of the marginal income in 2016 from 6531913 th. rubles to 8366770 th. rubles. It is also expected the increase of the rate of profit from $5 \%$ to $8.3 \%$, reflecting the increase of the company's profitability.

Application of optimizational financial model of expenses management allows JSC «Mostotrest»" to increase the level of the marginal income in 2016 from 520100 th. rubles to 681297 th. rubles. It is also expected the increase of the rate of profit from $4.9 \%$ to $6.5 \%$, reflecting the increase of the company's profitability.

In general, on the basis of the study the authors proposed a universal-optimization approach to financial modeling in the industrial construction with the use of the analytic hierarchy method, which allows to increase the rate of profit for each of the companies. This approach is representative and authentic, has universal nature, and can be applied to the analog organizations and be adapted to the different spheres of economic activity.

\section{References}

1. B.D. Baysinger, H.N. Butler, Journal of Law, Economics, and Organization, 1(1), 101-124 (1985)

2. T.B. Bell, S. Szykowny, J.J. Willingham, Assessing the Likelihood of Fraudulent Financial Reporting: A Cascaded Logit Approach (Working paper, KPMG Peat Marwick, Montvale, NJ, 1991)

3. J.A. Brickley, C.M. James, The Journal of Law and Economics, 30(April), 161-180 (1987)

4. R.S. Chaganti, V. Mahajan, S. Sharma, Journal of Management Studies, 22(July), 400-417 (1985)

5. H. DeAngelo, L. DeAngelo, The Journal of Finance, 45(December), 1415-1431 (1990)

6. H. DeAngelo, L. DeAngelo, D.J. Skinner, Journal of Accounting and Economics, 17(1-2), 113-143 (1994)

7. E.F. Fama, Journal of Political Economy, 88, 288308.

8. E.H. Feroz, K. Park, V.S. Pastena, Journal of Accounting Research, 29(Suppl.), 107-142 (1991)

9. S.C. Gilson, Journal of Financial Economics, 27(2), 355-387 (1990)

10. S.J. Grossman, O.D. Hart, The Bell Journal of Economics, 2(Spring), 42-64 (1980)

11. B. Hermalin, M.S. Weisbach, The Rand Journal of Economics, 19(Winter), 589-606 (1988)

12. M.C. Jensen, Journal of Law and Economics, 26(June), 301-325 (1983)
13. M.C. Jensen, The Journal of Finance, 48(July), 831880 (1993)

14. M.C. Jensen, W.H. Meckling, Journal of Financial Economics, 3(4), 305-360 (1976).

15. S.N. Kaplan, D. Reishus, Journal of Financial Economics, 27(2), 389-410 (1990)

16. R.D. Kosnik, Administrative Science Quarterly, 32, 163-185 (1987)

17. M.L. Mace, Directors: Myth and Reality (Harvard Business School Press, Boston, 1986)

18. G.S. Maddala, The Accounting Review, 66(October), 788-807 (1991)

19. R. Morck, A. Shleifer, R.W. Vishny, Journal of Financial Economics, 20(C), 293-315 (1988)

20. G. Novikova, A. Chub, J. Gushina, Globalization and its socio-economic consequences. 16 th International Scientific Conference, 1, 1547-1555 (2016)

21. K.G. Palepu, Journal of Accounting and Economics, 8(1), 3-35 (1986)

22. Z.V. Palmrose, Auditing: A Journal of Practice \& Theory, 6(Spring), 90-103 (1987)

23. A. Patton, J. Baker, Harvard Business Review, 65(November), 10-12 (1987)

24. K. Pincus, M. Rusbarsky, J. Wong, Journal of Accounting and Public Policy, 8(4), 239-265 (1989)

25. S. Rosenstein, J.G. Wyatt, Journal of Financial Economics, 26(2), 175-191 (1990)

26. A. Shivdasani, Journal of Accounting and Economics, 16(1-3), 167-198(1993)

27. A. Shleifer, R.W. Vishny, Journal of Political Economy, 95, 461-488 (1986)

28. A.A. Sommer, Accounting Horizons, (JUNE), 9193 (1991)

29. M. Stone, J. Rasp, The Accounting Review, 66(January), 170-187 (1991)

30. Financial Management, 20(Winter), 101-112 (1991)

31. R. Vancil, Passing the Baton: Managing the Process of CEO Succession (Harvard Business School Press, Boston, 1987)

32. D. Vicknair, K. Hickman, K.C. Carnes, Accounting Horizons, 7(March), 53-57 (1993)

33. J.B. Warner, R.L. Watts, K.H. Wruck, Journal of Financial Economics, 20(C), 461-492 (1988)

34. M.S. Weisbach, Journal of Financial Economics, 20(C), 431-460 (1988)

35. O.E. Williamson, The Yale Law Journal, 93, $1197-$ 1230 (1984) 